\title{
Survivin/p53/HER2 Antigen-loaded Autologous Dendritic Cell Vaccine
}

National Cancer Institute

\section{Source}

National Cancer Institute. Survivin/p53/HER2 Antigen-loaded Autologous Dendritic Cell

Vaccine. NCI Thesaurus. Code C114285.

An autologous dendritic cell (DC) vaccine loaded with tumor-associated antigens (TAAs) derived from survivin, p53 and human epidermal growth factor receptor 2 (HER2 or ERBB2), with immunostimulating and antineoplastic activities. Upon administration, this DC vaccine may elicit a potent cytotoxic $T$-cell $(C T L)$ response ag ainst tumor cells expressing these TAAs, resulting in tumor cell death. Survivin, p53 and HER2 are essential in neoplastic growth, and are considered to be universal tumor antigens. 